\title{
O JORNAL E O JORNALISTA DE AMANHÃ
}

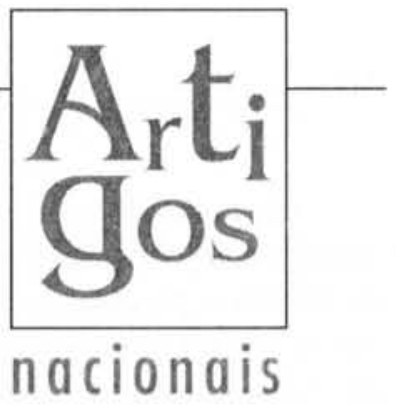

\section{De olho no amanhã, jornalismo tem desafio de transformar notícia em conhecimento para a cidadania}

Mais de 500 jornais diários dos Estados Unidos têm edições eletrônicas disponíveis via Internet. Cerca de $36 \%$ desses produtos são lucrativos ou deverão proporcionar resultados positivos até o final deste ano. Na América Latina estão localizados 110 provedores de conteúdo informativo ligados a jornais, 36 deles no Brasil. Só nos Estados Unidos, há mais de 900 serviços de voz e fax com informações econômicas, meteorológicas e de anúncios classificados ligados a jornais.

Ainda nos Estados Unidos, segundo a Newspaper Association of America (NAA), a porcentagem de adultos entre os leitores de jornais cai progressivamente desde os anos 70, especialmente nos dias úteis. Em 1970 , levantamento da NAA constatou que $77,6 \%$ da população acima de 18 anos lia pelo menos um jornal diariamente e $72,3 \%$ liam um jornal aos domingos. Em 1996, esses números caíram para $58,8 \%$ nos dias úteis e $68,5 \%$ nos fins de semana. Ao mesmo tempo, o universo de leitores se concentra cada vez mais no topo da pirâmide social, entre os mais educados e os de mais alta renda.

No Brasil, a circulação total dos diários quase dobrou dos anos 80 para os anos 90 , com um salto mais significativo entre 1992 e 1993, período da mobilização popular pelo impedimento do presidente
Fernando Collor de Mello. A circulação caiu em 1994, de um total de 6,3 milhões de exemplares diários, em média, para 5,9 milhões, mas a estratégia dos brindes nas edições dominicais e a estabilização da moeda empurraram as tiragens para cima, e o meio jornal quase chegou aos $6,6 \mathrm{mi}$ lhões de média diária em todo o país no ano seguinte.

Fecha-se o ano de 1997 com as carteiras de assinantes estagnadas em praticamente todos os grandes diários brasileiros. $\mathrm{O}$ que se obtém de crescimento nas tiragens resulta do oferecimento de brindes, geralmente nas edições de domingo, artifício que acaba se transformando em um negócio paralelo de promoções e pouco contribui para manter fiel o leitor. Nos grandes jornais, a fidelidade do assinante é fator importante para o planejamento estratégico, já que uma carteira sólida e composta por um extrato comprador representa argumento valioso na venda de anúncios. Além disso, uma base estável, não sujeita a quedas nos períodos de renovação, facilita a previsão de consumo de papel e outros custos.

\section{O AUTOR}

\section{Luciano Martins Costa}

Jornalista e escritor. Editor-executivo do jornal $O$ Estado de S. Paulo, responsável pela NetEstado.

E-mail: Imart@estado.com.br 
No entanto, enquanto os grandes jornais buscam consolidar os ganhos do início da década e procuram fidelizar o leitor, como se diz no jargão dos departamentos comerciais, cresce a circulação dos jornais médios e pequenos. Os levantamentos realizados pela Associação Nacional de Jornais (ANJ) revelam um amplo movimento de reformas e modernização fora dos grandes centros. Os quatro seminários regionais promovidos pela ANJ neste ano indicam uma rotina de investimentos em tecnologia e treinamento de jornalistas. A palavra de ordem na imprensa regional é: foco na comunidade. Dependentes das agências noticiosas pertencentes aos jornais de São Paulo e do Rio de Janeiro, esses jornais descobriram que não precisam repetir as manchetes da chamada grande imprensa para merecer a atenção dos seus leitores: a vida comunitária tem seus atrativos e o editor regional perde o medo de parecer provinciano.

\section{DESAFIOS NAS REDAÇÕES}

Mais do que uma crise, o cenário anuncia um grande desafio para a imprensa no Brasil. O meio criado pela associação da informática com as telecomunicações já não é visto como um perigo para o jornal. Ao contrário, a novidade tecnológica já foi absorvida pelas empresas jornalísticas e se transforma em instrumento para a expansão de marcas e conteúdos de imprensa para leitores localizados fora do alcance das malhas de distribuição do jornal-papel. Além disso, os pesados investimentos em tecnologia vêm melhorando a produtividade das redações e empurrando os gestores para fora de suas salas, levando-os a buscar modelos de administração mais adequados.

Passada a febre da reengenharia, que desfigurou algumas redações no começo dos anos 90, o que mais se ouve nos congressos de editores é o discurso sobre a necessidade de equilibrar os investimentos, de substituir o deslumbramento com os recursos técnicos por políticas de valorização dos recursos humanos.

Os novos sistemas editoriais, formatados como ilhas de edição autônomas e integradas, exigem uma nova qualificação dos profissionais: perde valor o especialista extremado, cresce em importância o jornalista capaz de compreender sua atividade de forma global e de agir nas várias etapas dos processos de coleta e processamento da informação.

No entanto, constata-se que os modelos de gestão atuais não são adequados às novas tecnologias disponíveis, ou seja, não basta introduzir as novas tecnologias nas redações para que elas passem a cumprir os fluxos e atender aos prazos cada vez mais curtos exigidos pelo processamento industrial e de distribuição de grandes tiragens. Casos relatados em congressos e conferências desde 1995 ilustram bem esse ritual de passagem, no qual os recursos tecnológicos disponíveis são subutilizados ou simplesmente somados à rotina de retrabalho e desperdício: na maioria das redações informatizadas o acúmulo de papel sobre as mesas passou a ser muito maior do que no tempo da velha Remington Rand ou da Olivetti. Ao mesmo tempo, estendeu-se a jornada dos profissionais, o que significa menos qualidade de vida, menos tempo para estudo e atualização e maior custo para as empresas.

Consultores externos e gerentes deslocados das áreas industriais e de recursos humanos têm colaborado para levar às redações metodologias e técnicas de planejamento até então desprezadas pelos gestores jornalistas. De forma mais ou menos gene- 
ralizada, o achômetro vem sendo substituído pela disciplina da gestão por processos, que tem como pressupostos a definição e a formalização de funções e responsabilidades e a descrição detalhada de cada etapa das ações que se iniciam com a elaboração da pauta até o fechamento da última edição.

O desafio de adequar os atuais modelos de gestão às novas tecnologias esbarra muito mais em resistências de caráter cultural do que nas condições objetivas das estruturas de redação. No topo da estrutura, é difícil a adaptação de jornalistas especialistas habituados às decisões editoriais baseadas na sensibilidade adquirida com a experiência. Na base, repórteres iniciantes escorregam na tentação de buscar em primeiro lugar a celebridade.

Os processos de aculturação, forçados geralmente pela exigência dos acionistas de que os investimentos em tecnologia resultem em maior produtividade e em métodos mais racionais de trabalho, têm produzido muito sofrimento e sobrecarga. A velha redação não cabe no jornal de amanhã: muitos gestores se mostram inseguros em abandonar as práticas associadas aos primeiros sistemas de informática baseados em unidades centrais de processamento, que utilizavam terminais burros, verdadeiras máquinas de datilografia eletrônicas interligadas.

\section{VALORES MURDOCH}

Os esforços por mudanças têm levado os gestores de jornais a buscar em outros setores da economia métodos avançados de administração, geralmente de difícil adaptabilidade ao ambiente criativo e improvisador das redações. Assim, certas técnicas de avaliação de desempenho, importadas de setores industriais, já provocaram decisões desastradas em muitas empresas jornalísticas, além do desperdício de oportunidades e de recursos financeiros. Outros instrumentos de mudança de cultura corporativa têm produzido efeitos muito benéficos, como as pesquisas de clima organizacional, que permitem avaliar o estado de espírito dos funcionários diante de questões muito específicas e medir a visão dos jornalistas sobre a qualidade do seu próprio trabalho.

Passada a febre da reengenharia e das consultorias milagrosas, desponta em alguns foros um novo conceito que pode abrigar os variados instrumentos de transformação. Trata-se da visão segundo a qual o jornal é um negócio de educação, não apenas um empreendimento de comunicação.

Diferentemente do civic journalism que viceja em algumas comunidades acadêmicas e jornais dos Estados Unidos, entre as quais se destaca a Universidade do Texas, em Austin, o conceito do jornal como negócio de educação exige um retorno às origens do meio e uma redefinição dos seus processos e rotinas. Em primeiro lugar, a edição deve se voltar muito mais para a comunidade do que para os agentes econômicos ou do poder político.

Trata-se de substituir a visão meramente mercadológica de que se impregnou a imprensa no final dos anos 80 , por uma atitude voltada para a sociedade, ou seja, o leitor não pode mais ser visto meramente como consumidor do produto jornal, mas tratado em sua inteira cidadania, como parceiro na elaboração das reflexões produzidas pelos fatos noticiados, também gerador de idéias que contribuam para o processo civilizatório.

Esse conceito é o que vai diferenciar o jornal dos novos meios e da televisão. Ele se revela na capacidade que terá o texto jornalístico de provocar reflexões no leitor e de 
afirmar claramente, diante da sociedade, valores substanciais para a convivência numa sociedade moderna. O repórter Carl Bernstein' produziu recentemente uma frase capaz de sintetizar essa tese: "trata-se de combater diariamente os valores Murdoch2". Bernstein se refere ao empresário Rupert Murdoch, cujos tablóides sensacionalistas ele cita como exemplos de um jornalismo irresponsável.

Há uma relação íntima entre as tecnologias mais recentes e essa nova visão do jornalismo. As agendas eletrônicas incluídas nos sistemas editoriais mais avançados permitem, por exemplo, uma inversão nos processos do jornal, reduzindo o esforço estressante do período de fechamento e antecipando para a etapa da pauta boa parte da energia que atualmente é despendida na correção de rumos e no cumprimento dos horários industriais cada vez mais restritos. Outro recurso, o da edição remota, permite delegar decisões editoriais importantes a sucursais, correspondentes ou equipes localizadas eventualmente fora da redação principal. A ênfase no planejamento exige partilha dos valores básicos que governam as escolhas do jornal e responsabilização.

Em ambos os casos, é preciso formar profissionais capazes de raciocinar mais amplamente do que é exigido hoje nas estruturas que utilizam jornalistas tarefeiros. A pauta deixa de ser o mero acompanhamento de fatos definidos pelas instituições políticas e outros agentes protocolares da sociedade, passando a representar uma atitude pro-ativa do jornal em relação a essas instituições. Os recursos de interatividade devem ser usados para auscultar os interesses da comunidade e a edição deve refletir claramente um jornalismo mais afirmativo.

O profissional precisa se educar para agir nesse ambiente mutante, a partir de uma sólida formação ética, deve entender o espírito das mudanças tecnológicas e de gestão e buscar um aprendizado que o torne capaz de filosofar sobre o negócio jornal. Na liderança do processo, já não cabe a figura do ditador em torno de cujas vontades e idiossincrasias circulava a antiga redação. Do editor exige-se, um perfil de estadista.

Essas considerações vêm sendo discutidas publicamente nos últimos encontros de editores de jornais brasileiros. Seus fundamentos derivam de alguns trabalhos de pesquisa realizados a partir de 1994, entre eles o estudo intitulado Configuração Futura do Jornal, produzido pelo Departamento de Planejamento e Pesquisa de $O$ Estado de $S$. Paulo a partir de ampla consulta sobre hábitos, necessidades e expectativas dos leitores.

Nesses debates e estudos, fica bastante claro que o crescimento das tiragens nos anos 90 esteve relacionado principalmente a dois fatores: a retomada das ações de cidadania, cujo ponto de partida pode ser representado pelo processo de impedimento do presidente Collor e envolve também a maior conscientização a respeito de direitos civis proporcionada pela nova Constituição, e a ênfase na função utilitária do meio jornal, que pode ser observada no crescimento das seções de serviços de todos os grandes diários e na estratégia da concessão de brindes.

1. Jornalista e escritor. Responsável, juntamente com Bob Woodward, pelas reportagens que levaram à renúncia do Presidente norte-americano Richard Nixon e que ficaram conhecidas como caso Watergate. Autor do best seller Todos os homens do Presidente. (N.E.)

2. O autor se refere à Rupert Murdoch, empresário australiano, proprietário de uma das maiores redes de empresas de comunicação do mundo, a News Corporation. Essa rede é formada por inúmeros jornais sensacionalistas nos Estados Unidos. Europa e Austrália e por empresas de mídia, entre elas a norte-americana Century Fox. (N.E.) 
A mudança que se impõe, segundo o que se deduz dos dados escolhidos no trabalho Configuração Futura do Jornal, diz respeito às funções informativa e de envolvimento distinguidas pelos leitores entre as excelências do meio jornal. A função informativa, tida tradicionalmente como a mais nobre da imprensa, recebe agora novas definições: o leitor quer mais aprofundamento, quer o diferencial que só pode ser obtido pelo esforço da investigação e que o coloca em posição de destaque no meio social pela capacidade de discorrer com propriedade sobre os fatos de conhecimento público.

Resumo: $\mathrm{O}$ artigo ressalta a importância de o jornal, enquanto empresa, e de o jornalista, enquanto profissional, estarem atentos para os desafios que se apresentam e a decorrente busca de novos métodos e processos de gerenciamento. Trata também da importância que adquiriu o jornalismo regional e a necessidade de essa prática voltar-se mais para a comunidade, para a educaçāo, extrapolando a visão que se tem do leitor como mero consumidor de informação, para vê-lo como cidadão, parceiro na elaboração e reflexão dos fatos noticiados.

Palavras-chave: jornal, qualificação do jornalista, gerenciamento, educação, cidadania
A função de envolvimento, descrita como a capacidade que tem o jornal de surpreender, emocionar e envolver o leitor, é uma exigência do chamado público emergente, aquela parcela de leitores atraída pelos brindes e outras promoções. São cidadãos que precisam de estímulos para aderirem ao meio jornal e que se consideram integrantes de uma nova elite ao se transformarem em leitores. Visto como um negócio de educação, o jornal precisa ser capaz de agregar à função informativa a função de envolvimento, de modo a transformar notícia em conhecimento. As tecnologias são ferramentas, algumas delas de utilidade duvidosa.

Abstract: The article emphasizes the importance of the newspaper, as a company, and of the journalist, as a professional, being aware of the challenges which appear and also of the resulting search for new management methods and processes. Furthermore, it stresses the importance that regional journalism has taken on and the need for this practice to turn itself more to the community, to education and, therefore, to extrapolating the view one has of the reader as a mere information consumer, to see him as a citizen, a partner in the elaboration and reflection on the facts that are transmitted.

Keywords: newspaper, journalist qualifications, management, education, citizenship 